\title{
Final Clauses
}

\section{ARTICLE 32. SIGNATURE}

This Protocol shall be open for signature by Parties to the Convention at the United Nations Headquarters in New York, from 2 February 2011 to 1 February 2012.

\section{ARTICLE 33. ENTRY INTO FORCE}

1. This Protocol shall enter into force on the ninetieth day after the date of deposit of the fiftieth instrument of ratification, acceptance, approval or accession by States or regional economic integration organisations that are Parties to the Convention.

2. This Protocol shall enter into force for a State or regional economic integration organisation that ratifies, accepts or approves this Protocol or accedes thereto after the deposit of the fiftieth instrument as referred to in paragraph 1 above, on the ninetieth day after the date on which that State or regional economic integration organisation deposits its instrument of ratification, acceptance, approval or accession, or on the date on which the Convention enters into force for that State or regional economic integration organisation, whichever shall be the later.

3. For the purposes of paragraphs 1 and 2 above, any instrument deposited by a regional economic integration organisation shall not be counted as additional to those deposited by member States of such organisation.

\section{ARTICLE 34. RESERVATIONS}

No reservations may be made to this Protocol.

\section{ARTICLE 35. WITHDRAWAL}

1. At any time after two years from the date on which this Protocol has entered into force for a Party, that Party may withdraw from this Protocol by giving written notification to the Depositary. 
2. Any such withdrawal shall take place upon expiry of one year after the date of its receipt by the Depositary, or on such later date as may be specified in the notification of the withdrawal.

\section{ARTICLE 36. AUTHENTIC TEXTS}

The original of this Protocol, of which the Arabic, Chinese, English, French, Russian and Spanish texts are equally authentic, shall be deposited with the Secretary-General of the United Nations.

\section{Overview}

Articles 32-36 are standard closing provisions of international (environmental) treaties. ${ }^{1}$ They were not subject to negotiation, ${ }^{2}$ and to a great extent replicate the text of the Convention. ${ }^{3}$ As in any other international treaty, these provisions apply from the moment of the Protocol adoption, rather than its entry into force. ${ }^{4}$ The following sections will address any specific issues related to the Protocol that arise in the context of these provisions.

At the time of writing, the Protocol attracted 92 Signatures, ${ }^{5}$ with many States and the European Union already taking legislative and other action to

1 See generally on the signature, ratification and entry info force of treaties: Aust, Modern Treaty Law and Practice, op. cit., chapters 7-9; on the final clauses of the Nagoya Protocol specifically, Greiber et al., Explanatory Guide, op. cit., 253-264; and on the Eu's participation in multilateral environmental agreements, see Marín Durán and Morgera, Environmental Integration in the EU's External Relations, op. cit., 17-24.

2 These Articles were first incorporated in the Cali Draft.

3 Nagoya Protocol Article 33 is modelled after Biosafety Protocol Article 37 (see comments by Mackenzie et al., Explanatory Guide to the Cartagena Protocol, op. cit., 201 on that provision) and corresponds to СBD Articles 38(2) and (4-5). Nagoya Protocol Article 34 reiterates свр Article 38(1-2). Nagoya Protocol Article 35 replicates свр Article 38(1)-(2); and Nagoya Protocol Article 36 mirrors exactly the text of свD Article 42.

4 Aust, Modern Treaty Law and Practice, op. cit., 162.

5 As mentioned above (this commentary on Article 1, fn. 63), at the time of writing the Protocol had 92 signatures and 26 ratifications. 
implement the Protocol. ${ }^{6}$ According to the law of treaties, after a government signs the Protocol, the State is obliged to refrain from acts that could defeat the object and purpose of the Protocol, ${ }^{7}$ unless the State manifests its intention not to become a Party to it. ${ }^{8}$ This implies that a State must avoid any act preventing it from being able to fully comply with the Protocol once it enters into force, ${ }^{9}$ or an act that would invalidate the basic purpose of the Protocol. ${ }^{10}$

Once the Protocol enters into force, ${ }^{11}$ its obligations may take effect at different times for those States that will become Parties to it at a later stage. This may have particular relevance for provisions in the Protocol that refer to the 'Party providing genetic resources', rather than countries providing such resources. ${ }^{12}$ In other words, if there are ABs transactions that involve Parties to the Protocol and CBD Parties that are not yet Parties to the Protocol, the latter will be only subject to the relevant $\mathrm{CBD}$ provisions.

\section{Reservations}

The Protocol includes an absolute prohibition for Parties to make reservations, ${ }^{13}$ which can be explained by the desire to preserve the balance between the

6 "Progress Report on the Nagoya Protocol on Access to Genetic Resources and the Fair and Equitable Sharing of Benefits Arising from their Utilization and Related Developments," $\mathrm{UNEP} / \mathrm{CBD} / \mathrm{COP} / 11 / 11$ and ADD.1.

7 See this commentary on Article 1.

8 VCLT Article 18, which reads: 'A State is obliged to refrain from acts which would defeat the object and purpose of a treaty when: $(a)$ it has signed the treaty or has exchanged instruments constituting the treaty subject to ratification, acceptance or approval, until it shall have made its intention clear not to become a Party to the treaty; or $(b)$ it has expressed its consent to be bound by the treaty, pending the entry into force of the treaty and provided that such entry into force is not unduly delayed.'

9 It should be recalled that Свр Article 34 applies also to the ratification, acceptance and accession to СвD Protocols, including questions related to 'Regional Economic Integration Organisations' - an expression that applies to the European Union.

10 Aust, Modern Treaty Law and Practice, op. cit., 119.

11 As mentioned in this commentary on Article 1, fn. 63, at the time of writing the Protocol had 25 ratifications.

12 Similarly to Свр Article 15(3): see comments by Glowka, Burhenne-Guilmin and Synge, Guide to the Convention on Biological Diversity, op. cit., 127.

13 VCLT Article 19, which reads: 'A State may, when signing, ratifying, accepting, approving or acceding to a treaty, formulate a reservation unless: $(a)$ the reservation is prohibited by the treaty (...).' See also vCLT Articles 20-23. 
various obligations created by the Protocol. ${ }^{14}$ This is in effect quite a common provision in other multilateral environmental agreements. ${ }^{15}$

While States are precluded from making a formal declaration that they do not consider themselves bound by some of the Protocol's provisions, ${ }^{16}$ at the time they take the action needed to become a Party to the Protocol, the possibility cannot be excluded that States may try to achieve the effect of a reservation through an interpretative declaration. ${ }^{17}$ The latter, although in principle it is not intended to have any legal effect in respect of the treaty at stake, may go beyond expressing the preference for an interpretation of the Protocol that is consistent with the domestic law of the State concerned, and rather aims at excluding or modifying the legal effect of certain provisions of the Protocol in their application to the State. ${ }^{18}$ At the time of writing, however, no declarations have been made on the Protocol. Pragmatically, it can be observed that the Protocol's open-ended and heavily qualified language may already provide sufficient flexibility to Parties, thereby lessening their desire to make declarations. ${ }^{19}$

\section{$4 \quad$ Withdrawals}

With regard to withdrawals ${ }^{20}$ from the Protocol, it should be noted that any Party to the Protocol that withdraws from the СвD will automatically withdraw from the Protocol too. ${ }^{21}$

14 Similarly to the свр Article 37: see Glowka, Burhenne-Guilmin and Synge, Guide to the Convention on Biological Diversity, op. cit., 124.

15 The prohibition of reservations is typical of treaties negotiated by consensus and as a package deal, and intends to express the Parties' intention to create a single integral and interdependent treaty regime not open to contracting out: Boyle and Chinkin, Making of International Law, op. cit., 255.

16 Aust, Modern Treaty Law and Practice, op. cit., chapter 8.

17 We are grateful to Riccardo Pavoni for drawing out attention to this point. If an interpretative declaration is genuine (i.e., it is not a 'disguised reservation'), it can become an element in the interpretation of the Protocol, if no other Parties makes conflicting declarations or otherwise indicates disagreement:vclt Article 31(2)(b) and Aust, Modern Treaty Law and Practice, op. cit., 127-128.

18 Ibid., 126-131.

19 We are grateful to Riccardo Pavoni for drawing out attention to this point.

20 VCLT Article 54(a).

21 As a result of combined reading of СBD Articles 38(3) and 32. 
Withdrawals from multilateral environmental agreements have occurred in the recent past, ${ }^{22}$ so future research should consider the possible effects of a Party withdrawing from the Protocol on ABS arrangements concluded while the Protocol was in force for that Party. ${ }^{23}$

\section{$5 \quad$ Official Languages}

The Protocol was negotiated and adopted in the six official languages of the United Nations: all of its texts are equally authentic, thus they are presumed to have the same meaning. ${ }^{24}$ Of note are the corrections made to the French version of the Protocol, which were announced by the CBD Secretariat on 27 June 2011. As no objections were received, the French version of the original text of the Nagoya Protocol was amended accordingly. 25

Any further cases of discrepancies between authentic language versions of the Protocol that may be identified in the future will be resolved either by interpretation, giving precedence - when the general rules of interpretation and supplementary means of interpretation fail - to the meaning which best reconciles the texts, having regard to the object and purpose of the

22 On 15 December 2011, the Government of Canada notified the UN Secretary-General that it had decided to withdraw from the Kyoto Protocol with effect from 15 December 2012: "Kyoto Protocol to the United Nations Framework Convention on Climate Change," UN Treaty Collection, accessed 30 November 2013, <http://treaties.un.org/ pages $/$ ViewDetails.aspx?src=TREATY\&mtdsg_no $=$ XXVII-7-a\&chapter $=27 \&$ lang $=$ en $>$. On 29 March 2013, Canada notified the UN Secretary-General its decision to withdraw from the UNCCD: "UN Convention to Combat Desertification Responds to Canada's Withdrawal from Convention," un Convention to Combat Desertification, accessed 30 November 2013, <www.unccd.int/en/media-center/MediaNews/Pages/highlightdetail .aspx?HighlightID $=181>$ (not yet reported on the UnTs database).

23 On treaty withdrawal, see Duncan B. Hollis, The Oxford Guide to Treaties (Oxford: Oxford University Press, 2012), 639-640; and James Crawford, Brownlie's Principles of Public International Law (Oxford: Oxford University Press, 2012), 390-391.

24 VCLT Article 33(3).

25 CвD, Notification: Corrections du texte original de la version française du Protocole de Nagoya sur l'accès aux ressources génétiques et le partage des avantages (27 June 2011), accessed 30 October 2012, <www.cbd.int/doc/notifications/2011/ntf-2011-211-abs-fr.pdf> (only available in French). 
Protocol, ${ }^{26}$ or by amendment of one or more versions. ${ }^{27}$ In either case, Parties will likely engage in negotiations in the framework of the Protocol's governing body. ${ }^{28}$

26 VCLT Article 33(4); Jonas and Saunders, "The Object and Purpose of a Treaty," op. cit., 574. See this commentary on Article 1.

27 Glowka, Burhenne-Guilmin and Synge, Guide to the Convention on Biological Diversity, op. cit., 129.

28 Nagoya Protocol Article 26(4)(a) and this commentary on Article 26, section 2. For an example of a possible discrepancy between the authentic language versions of the Protocol, see this commentary on Article 15, section 3.1, fn. 31 . 